\title{
TYT Curve: Pilot Study on Alternatives Standards of Reference to Determine Intrauterine Growth in Low Resource Setting in Indonesia
}

\author{
Tina Dewi Judistiani, ${ }^{1}$ Tetty Yuniaty, ${ }^{2}$ Yessika Adelwin Natalia ${ }^{3}$ \\ ${ }^{1}$ Department of Epidemiology and Biostatistics, Faculty of Medicine, Universitas Padjadjaran \\ ${ }^{2}$ Department of Child Health, Faculty of Medicine, Universitas Padjadjaran-Dr. Hasan Sadikin General Hospital \\ ${ }^{3}$ Faculty of Medicine, Universitas Padjadjaran-Dr. Hasan Sadikin General Hospital
}

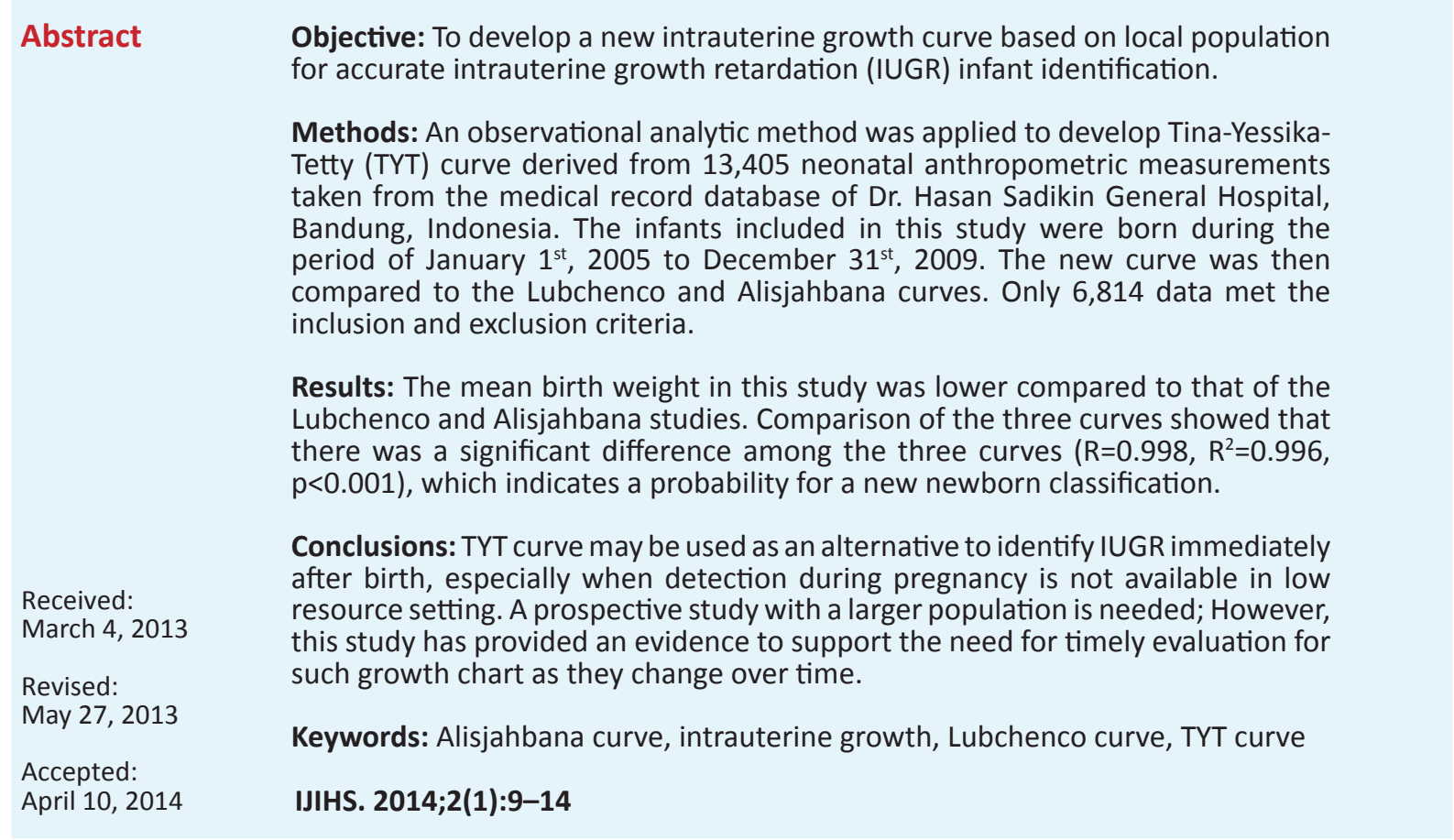

\section{Introduction}

Infant mortality is still considered to be one of the major health problems in Indonesia. In 2010, data from Statistics Indonesia show that the infant mortality rate (IMR) in this country was 26.89 per 1000 live births in 2010. ${ }^{1}$ This rate is higher than the rate targeted in the Millenium Development Goals (MDGs), which is 23 per 1,000 live births by year $2015 .^{2}$ Infant deaths related to low birth weight comprised around $11.5 \%$ from all births, mainly caused by intrauterine growth restriction (IUGR) with a prevalence of about $4.4 \% .^{3-7}$ The IUGR was also considered to be responsible for $26 \%$ of stillbirths and may increase infant mortality and morbidity by 7 to 8 times. $^{8}$ Some IUGR related morbidities

\footnotetext{
Correspondence:

Yessika Adelwin Natalia, Faculty of Medicine, Universitas

Padjadjaran-Dr. Hasan Sadikin General Hospital

Jl. Pasteur No. 38, Bandung, Indonesia

e-mail: yessika.adelwin@yahoo.com
}

are also found later in life such as hypertension, coronary heart disease, diabetes mellitus type 2, obesity, osteoporosis, and metabolic syndrome. ${ }^{8-14}$ For that reason, IUGR prevention, early detection, and appropriate management are required, which starts with the intrauterine growth evaluation. ${ }^{15}$ The gold standard for IUGR diagnosis is serial ultrasonography throughout pregnancy, but it is not evenly accessible to all patients. ${ }^{6,16}$ An indirect method by plotting newborns anthropometric measurement into a growth curve is considered more suitable for use in population, providing that the intrauterine growth curve is kept 'current'. The Lubchenco curve is still used as the standard in Indonesian hospitals. This curve was developed in American population, which leads to a situation where the genetic differences may inhibit its suitability to be used for other population. ${ }^{17,18}$ Many researchers kept updating intrauterine growth curve for their population, including those in United States, which is the country of origin of 
the Lubchenco curve. ${ }^{19-21}$ Alisjahbana et al. ${ }^{22}$ had developed an intrauterine growth curve for the Indonesian population. ${ }^{23}$ Since the curve was dated in 1994, the changes in fetal growth rate may limit its suitability for current use. Therefore, consequently, a new curve should be developed based on our population. Therefore, this study aimed to develop a new intrauterine growth curve based on our population to make identifications of IUGR babies more appropriate.

\section{Methods}

Data for this study were retrieved from the Child Health Department and Obstetrics Department of Dr. Hasan Sadikin General Hospital, Bandung for the anthropometric measurement and maternal complications, respectively, during the period of January $1^{\text {st }}, 2005$ to December $31^{\text {st }}, 2009$. Dr. Hasan Sadikin General Hospital, Bandung is the top referral hospital in West Java; therefore, the subjects came from surrounding areas in West Java. Inclusion criteria were live birth, singleton pregnancy, and precise menstrual period of the mother. The exclusion criteria were gestational age less than 34 weeks and/or more than 42 weeks, since data from these gestational age periods were not available in any of Lubchenco or Alisjahbana studies. Infants with congenital defect, maternal IUGR-related complication of pregnancy such as hypertension, tuberculosis, diabetes mellitus, hepatitis B infection, cardiac defect, anemia, and high fever. Cases with missing data were also excluded.

The gestational age was calculated from the

Table 1 Study Subjects Characteristics

\begin{tabular}{|c|c|c|c|c|c|c|}
\hline \multirow{2}{*}{ Criteria } & \multicolumn{2}{|c|}{ Male } & \multicolumn{2}{|c|}{ Female } & \multicolumn{2}{|c|}{ Both } \\
\hline & $\mathbf{n}$ & $\%$ & $\mathbf{n}$ & $\%$ & $\mathbf{n}$ & $\%$ \\
\hline Live birth & 3,610 & 53.0 & 3,204 & 47.0 & 6,814 & 100 \\
\hline \multicolumn{7}{|c|}{ Gestational age (weeks) } \\
\hline $28-36$ & 335 & 4.3 & 294 & 4.9 & 629 & 9.2 \\
\hline $37-42$ & 3,275 & 42.7 & 2,910 & 48.1 & 6,185 & 90.8 \\
\hline \multicolumn{7}{|c|}{ Birth weight (grams) } \\
\hline$<1,000$ & 0 & 0 & 0 & 0 & 0 & 0 \\
\hline $1,000-2,499$ & 355 & 5.2 & 367 & 5.4 & 722 & 10.6 \\
\hline 2,500-3,999 & 3,206 & 47.1 & 2,819 & 41.4 & 6,025 & 88.4 \\
\hline$\geq 4,000$ & 49 & 0.7 & 18 & 0.3 & 67 & 1.0 \\
\hline
\end{tabular}

Table 2 Male Birth Weight Percentiles by Gestational Age

\begin{tabular}{ccccccccc}
\hline $\mathbf{G A}$ & $\mathbf{n}$ & $\begin{array}{c}\mathbf{1 0}^{\text {th }} \\
\text { percentile }\end{array}$ & $\begin{array}{c}\mathbf{2 5}^{\text {th }} \\
\text { percentile }\end{array}$ & $\begin{array}{c}\mathbf{5 0}^{\text {th }} \\
\text { percentile }\end{array}$ & $\begin{array}{c}\mathbf{7 5}^{\text {th }} \\
\text { percentile }\end{array}$ & $\begin{array}{c}\mathbf{9 0}^{\text {th }} \\
\text { percentile }\end{array}$ & Mean & SD \\
\hline 34 & 68 & 1,632 & 1,750 & 1,935 & 2,300 & 2,786 & 2,371 & 530.7 \\
35 & 105 & 1,723 & 1,900 & 2,200 & 2,450 & 2,858 & 2,523 & 506.0 \\
36 & 162 & 1,942 & 2,100 & 2,459 & 2,750 & 3,135 & 2,786 & 508.9 \\
37 & 393 & 2,250 & 2,400 & 2,630 & 2,900 & 3,250 & 2,941 & 438.7 \\
38 & 678 & 2,330 & 2,500 & 2,750 & 3,013 & 3,275 & 3,011 & 387.7 \\
39 & 897 & 2,418 & 2,600 & 2,850 & 3,125 & 3,400 & 3,127 & 405.4 \\
40 & 830 & 2,500 & 2,656 & 2,900 & 3,200 & 3,488 & 3,187 & 398.7 \\
41 & 322 & 2,600 & 2,730 & 2,994 & 3,220 & 3,470 & 3,223 & 367.9 \\
42 & 158 & 2,499 & 2,600 & 2,904 & 3,200 & 3,450 & 3,185 & 400.8 \\
\hline
\end{tabular}


maternal first day of the last menstrual period to the date of birth. Scattered plot graphics for every newborn were then further developed to create the Tina-Yessika-Tetty (TYT) curve model. The mean birth weight was calculated for each gestational age group and sex. Identification of IUGR based on the three curves under study was then carried out.

\section{Results}

There were 13,405 newborns recorded during the selected period consisting of 7,067 male and 6,338 female newborns. Exclusion from this study were done for the following reasons: 51 cases of missing data, 754 stillbirths, 2 infants with sexual ambiguity, 522 with uncertain maternal last menstrual period, 540 multiple gestations, 2,000 cases of possible congenital anomalies, and 2,111 cases of IUGR-related maternal complications leading to a total inclusion of 7,425 newborns, i.e. 3,924 male and 3,501 female infants.

Outliers during statistical analysis were ruled out leading to 6,814 clean data $(50.83 \%$ of original data) with 3,610 male infants (52.98\%) and 3,204 female infants (47.02\%).

The characteristics of the subjects show that most of the newborns had a gestational age of 37 to 42 weeks and a weight of between 2,500 and 3,999 grams (Table 1).

The $10^{\text {th }}, 25^{\text {th }}, 50^{\text {th }}$ (median), $75^{\text {th }}$, and $90^{\text {th }}$ percentile as well as the mean and SD birth weights for male, female, and both sex infants are presented (Table 2, 3, and 4). A final weightfor-gestational age curves for female and male infants were then created (Fig. 1).
The crude curves show some "bumps" in several percentiles, leaving some assumptions that some truly term births are misclassified at these gestational ages.

The TYT curve was compared to Lubchenco and Alisjahbana curves. The comparison of mean birth weight for each curve is presented (Fig. 2).

Generally, the TYT study curve had lower average weights for each gestational age compared to the Lubchenco curve except for 3437 weeks. Compared to the Alisjahbana curve, the TYT curve also generally had lower average weights except for 37-39 weeks. The curve model estimation showed that the appropriate model was the quadratic regression model.

For the Lubchenco curve, the formula to estimate birth weight is $-21043.733+1134.926$ x GA - 13.208 x GA2 (R2=0.992, $p<0.001)$ while for Alisjahbana curve the formula is $-4661.533+$ $317.166 \times$ GA - 3.067 x GA2 (R2=0.968, p>0.05). TYT study curve formula to estimate birth weight is $-24852.567+1365.165 \times$ GA $-16.635 \times$ GA2 $(R 2=0.996, p<0.001)$.

After all data were plotted into the TYT study curve, a significant difference among the three curves was found (Fig. 3).

\section{Discussion}

The differences of the 'normal' standard of reference birth weight per gestational age and sex between the TYT, Lubchenco, and Alisjahbana curves support the need for updated gestational age and gender-specific growth curves for certain population.

The three curves used quite a reasonable

Table 3 Female Birth Weight Percentiles by Gestational Age

\begin{tabular}{ccccccccc}
\hline $\mathbf{G A}$ & $\mathbf{n}$ & $\begin{array}{c}\mathbf{1 0}^{\text {th }} \\
\text { percentile }\end{array}$ & $\begin{array}{c}\mathbf{2 5}^{\text {th }} \\
\text { percentile }\end{array}$ & $\begin{array}{c}\mathbf{5 0}^{\text {th }} \\
\text { percentile }\end{array}$ & $\begin{array}{c}\mathbf{7 5}^{\text {th }} \\
\text { percentile }\end{array}$ & $\begin{array}{c}\mathbf{9 0}^{\text {th }} \\
\text { percentile }\end{array}$ & Mean & SD \\
\hline 34 & 66 & 1,332 & 1,578 & 1,926 & 2,243 & 2,563 & 2,243 & 510.7 \\
35 & 96 & 1,799 & 2,099 & 2,309 & 2,683 & 3,040 & 2,654 & 461.9 \\
36 & 132 & 2,100 & 2,215 & 2,400 & 2,630 & 2,963 & 2,685 & 389.8 \\
37 & 311 & 2,084 & 2,254 & 2,500 & 2,765 & 3,090 & 2,803 & 438.9 \\
38 & 574 & 2,359 & 2,463 & 2,664 & 2,915 & 3,236 & 2,951 & 386.6 \\
39 & 814 & 2,425 & 2,550 & 2,770 & 3,000 & 3,300 & 3,036 & 390.1 \\
40 & 736 & 2,450 & 2,575 & 2,800 & 3,075 & 3,335 & 3,084 & 389.5 \\
41 & 338 & 2,405 & 2,598 & 2,850 & 3,100 & 3,393 & 3,109 & 395.5 \\
42 & 141 & 2,500 & 2,657 & 2,838 & 3,040 & 3,318 & 3,083 & 358.2 \\
\hline
\end{tabular}




\section{A. Male}

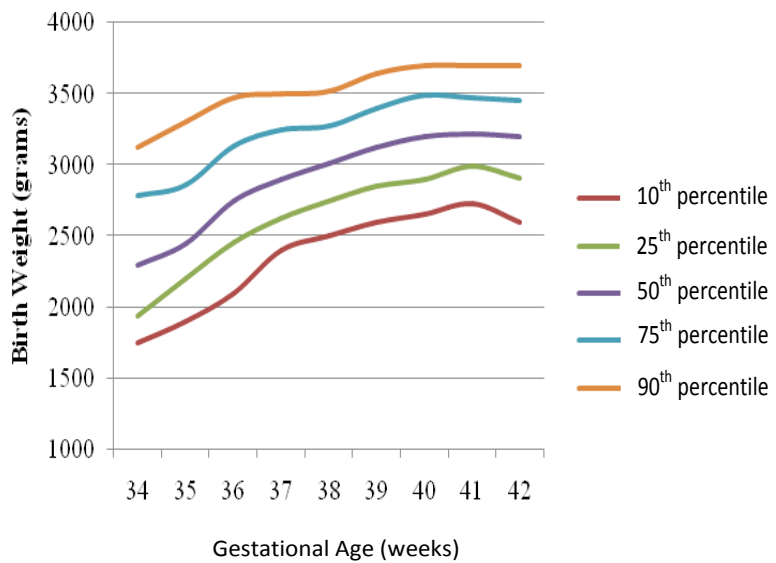

\section{Combined}

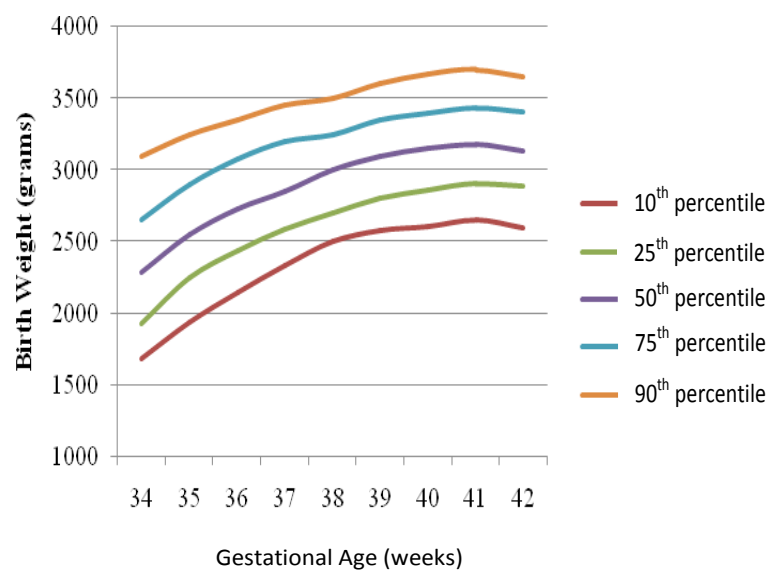

\section{B. Female}

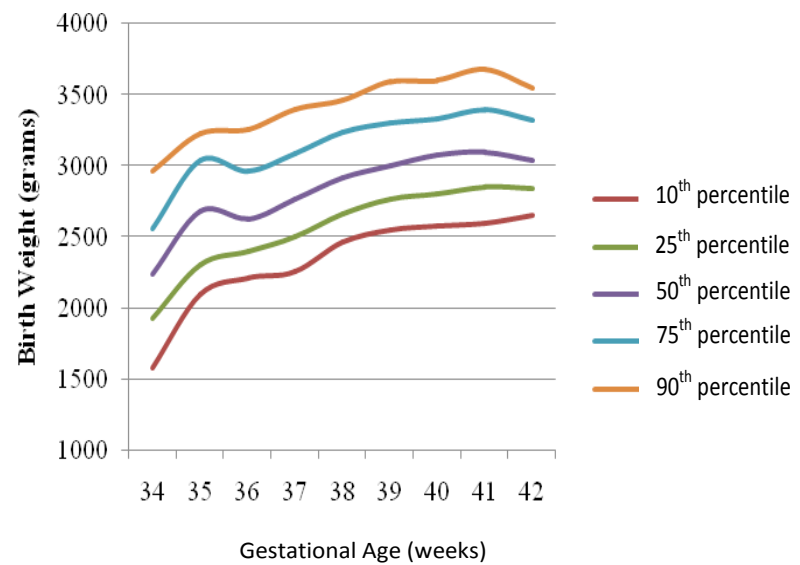

Fig. 1 TYT Study Curve (Gender Specific and Combined). TYT Study Curve for: (A) Male Infants, (B) Female Infants, (C) Both Sex

sample size of more than 5,000 births in each study. The Lubchenco curve offers advantages over the Alisjahbana curve due to a reasonable small grid increments (i.e., weekly for GA; every $200 \mathrm{~g}$ of weight; percentiles (versus SDs from mean)) for easier interpretation. The Alisjahbana curve offers superiority in terms of data sources that was retrieved from 14 hospitals in Indonesia.

There are similar drawbacks found in the three studies. First, there are possible errors in the gestational age calculation. To get more accurate gestational age, ultrasonography can be perfomed during the first trimester. Second, the limited population at Dr. Hasan Sadikin
General Hospital due to the fact that most patients came from West Java makes this curve may not be appropriate for the whole Indonesian population.

Prospective, multicenter research is needed to represent all Indonesian populations, especially from centers where ultrasonography is available. The use of the TYT curve value to determine intrauterine growth should be assessed in larger population.

It is concluded from this study that the new gender-specific intrauterine growth curves created will provide clinicians with an updated tool for the assessment of newborn intrauterine 


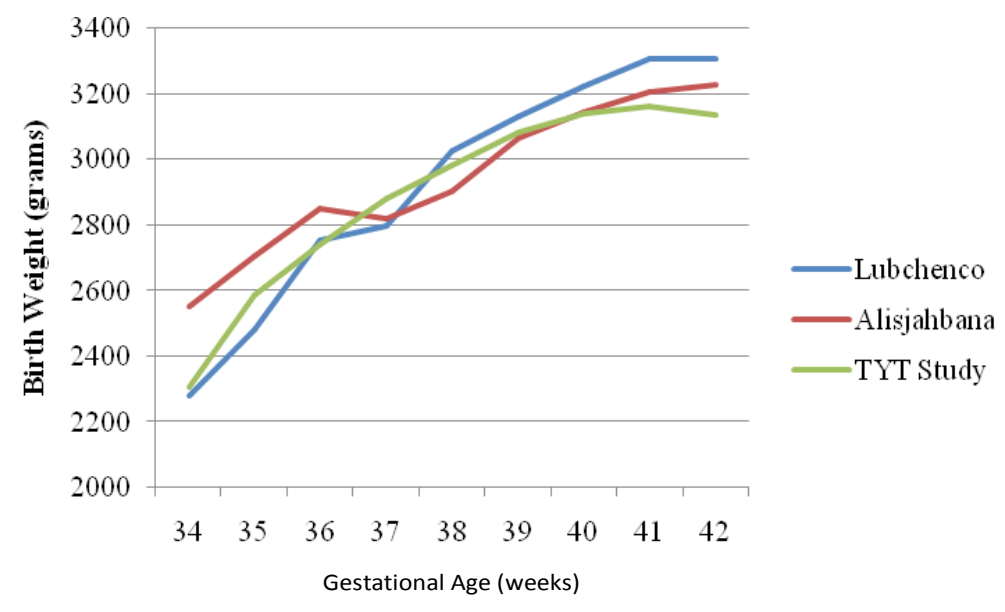

Fig. 2 Comparison of Mean Birth Weight for Each Gestational Age from Lubchenco, Alisjahbana, and TYT Study Curve

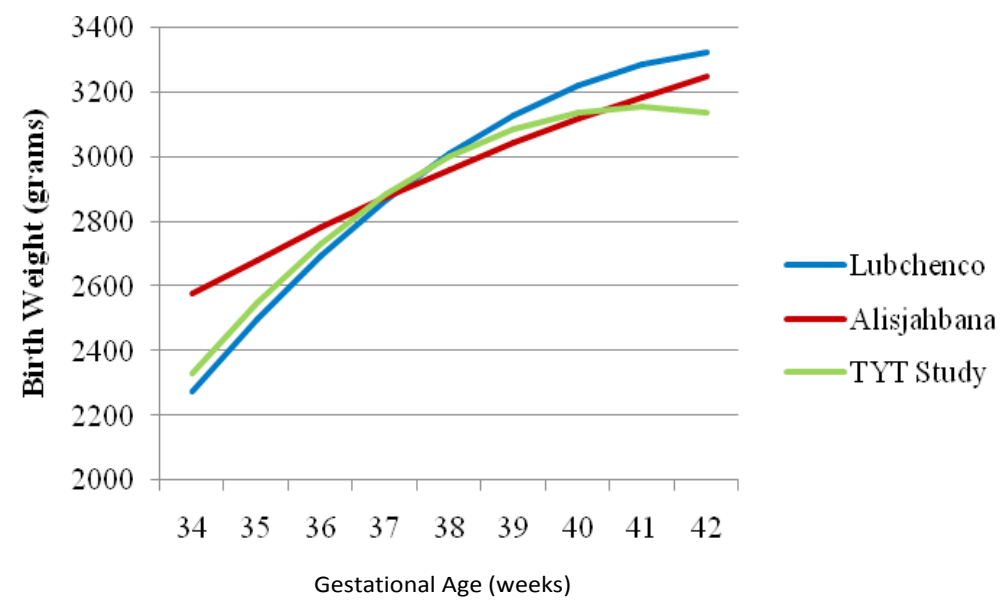

Fig. 3 Comparison of Quadratic Regression Curve of Mean Birth Weight from Lubchenco, Alisjahbana, and TYT Study Curve

growth status in West Java.

We strongly suggest nation-wide research using ultrasonography to assess gestational age more accurately starting in the first trimester.
Acknowledgements

We thank Dr. Hadiyana Sukandar, drs., MSc for the statistical assistance.

\section{References}

1. Badan Pusat Statistik. Perkembangan beberapa indikator utama sosial-ekonomi Indonesia. Jakarta: Statistics Indonesia; 2010.

2. Badan Perencanaan Pembangunan Nasional

(BAPPENAS). Laporan pencapaian tujuan pembangunan milenium di Indonesia 2010. Jakarta: 2010.

3. Badan Penelitian dan Pengembangan Kesehatan. 
Laporan Hasil Riset Kesehatan Dasar (RISKESDAS) Nasional. 2007 [cited 2013 October 19]. Available from: http://www.litbang.depkes.go.id/bl_ riskesdas2007.

4. World Health Organization. Nutrition landscape information system country profile indicators interpretation guide 2010. [cited 2013 October 19]. Available from: http://www.who.int/ nutrition/nlis/en/.

5. United Nations Children's Fund. Child Info: Monitoring the situation of children and women statistics by area child nutrition low birth weight. 2009 [updated November 2009; cited 2010 October 19]. Available from: http://www. childinfo.org/low_birthweight_table.php.

6. Cunningham FG, Leveno KJ, Bloom SL, Hauth JC, Gilstrap LCl, Wenstrom KD. Williams obstetrics. $22^{\text {nd }}$ ed. New York: McGraw-Hill; 2005.

7. Ross MG, Mansano RZ. Fetal growth restriction. 2010 [updated 2013 May 8; cited 2013 October 19]. Available from: http://www.emedicine. medscape.com/article/261226.

8. Pasaribu HP. Pertumbuhan janin terhambat. Medan: 2009 [cited 2013 October 19]. Available from: http://repository.usu.ac.id/bitstream/123 456789/6466/1/09E00704.pdf.

9. Gluckman PD, Hanson MA, Cooper C, Thornburg $\mathrm{KL}$. Effect of in utero and early-life conditions on adult health and disease. N Engl J Med. 2008;359(1):61-73.

10. Kensara OA, Wootton SA, Phillips DI, Patel M, Jackson AA, Elia M. Fetal programming of body composition: relation between birth weight and body composition measured with dual-energy X-ray absorptiometry and anthropometric methods in older Englishmen. Am J Clin Nutr. 2005;82(5):980-7.

11. Elia $M$, Betts $P$, Jackson DM, Mulligan J. Fetal programming of body dimensions and percentage body fat measured in prepubertal children with a 4-component model of body composition, dualenergy X-ray absorptiometry, deuterium dilution, densitometry, and skinfold thicknesses. Am J Clin Nutr. 2007;86(3):618-24.

12. Hemachandra $A H$, Howards $P P$, Furth $S L$, Klebanoff MA. Birth weight, postnatal growth, and risk for high blood pressure at 7 years of age: results from the Collaborative Perinatal Project. Pediatrics. 2007;119(6):e1264-70.
13. Shankaran S, Das A, Bauer CR, Bada H, Lester B, Wright $L$, et al. Fetal origin of childhood disease: intrauterine growth restriction in term infants and risk for hypertension at 6 years of age. Arch Pediatr Adolesc Med. 2006;160(9):977-81.

14. Rueda-Clausen CF, Morton JS, Davidge ST. Effects of hypoxia-induced intrauterine growth restriction on cardiopulmonary structure and function during adulthood. Cardiovascular Research. 2009;81(4):713-22.

15. World Health Organization Expert Committee on the Use and Interpretation of Anthropometry. Physical status: the use and interpretation of anthropometry. Geneva, Switzerland: World Health Organization; 1995.

16. DeCherney AH, Nathan L, Goodwin TM, Laufer N, editors. Current diagnosis \& treatment obstetrics \& gynecology. $10^{\text {th }}$ ed. New York: McGraw-Hill; 2007.

17. Lubchenco LO, Hansman C, Dressler M, Boyd E. Intrauterine growth as estimated from liveborn birth-weight data at 24 to 42 weeks of gestation. Pediatrics. 1963;32(5):793-800.

18. Lubchenco LO, Hansman C, Boyd E. Intrauterine growth in length and head circumference as estimated from live births at gestational ages from 26 to 42 weeks. Pediatrics. 1966;37(3):4038.

19. Kramer MS, Platt RW, Wen SW, Joseph KS, Allen A, Abrahamowicz $M$, et al. A new and improved population-based Canadian reference for birth weight for gestational age. Pediatrics. 2001;108(2):e35.

20. Olsen IE, Groveman SA, Lawson ML, Clark RH, Zemel BS. New intrauterine growth curves based on United States data. Pediatrics. 2010;125(2):e214-24.

21. Fenton TR. A new growth chart for preterm babies: Babson and Benda's chart updated with recent data and a new format. BMC Pediatr. 2003;3(1):13.

22. Alisjahbana A, Chaerulfatah A, Usman A, Sutresnawati S. Anthropometry of newborn infants born in 14 teaching centers in Indonesia. Paedtr Indones. 1994;34:62-123.

23. Mandruzzato $G$, Antsaklis A, Botet F, Chervenak FA, Figueras F, Grunebaum A, et al. Intrauterine restriction (IUGR). J Perinat Med. 2008; 36(4):277-81. 